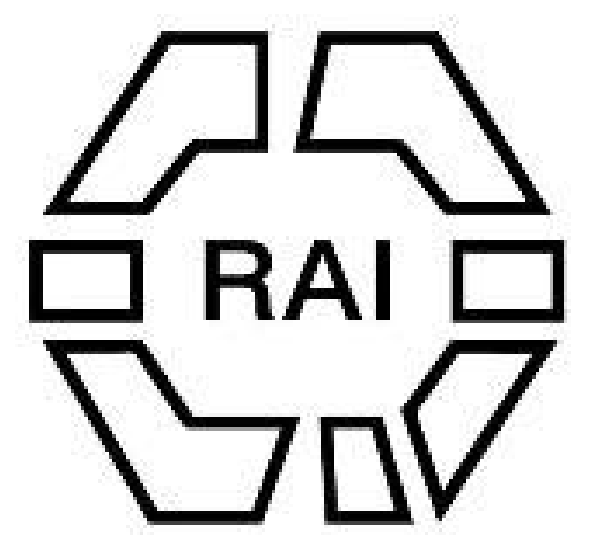

\title{
WILEY
}

\section{Note on an Unusually Fine Bronze Figure from Benin.}

\author{
Author(s): O. M. Dalton
}

Source: Man, Vol. 3 (1903), p. 185

Published by: Royal Anthropological Institute of Great Britain and Ireland

Stable URL: http://www.jstor.org/stable/2840542

Accessed: 27-06-2016 05:11 UTC

Your use of the JSTOR archive indicates your acceptance of the Terms \& Conditions of Use, available at

http://about.jstor.org/terms

JSTOR is a not-for-profit service that helps scholars, researchers, and students discover, use, and build upon a wide range of content in a trusted digital archive. We use information technology and tools to increase productivity and facilitate new forms of scholarship. For more information about JSTOR, please contact support@jstor.org.

Royal Anthropological Institute of Great Britain and Ireland, Wiley are collaborating with JSTOR to digitize, preserve and extend access to Man 
with assiduity to prehistoric studies. The implement-bearing gravels and brick-earths in the neighbourhood of his residence at Ealing afforded excellent exposures some fiveand-twenty years ago, and Mr. Brown was not slow to avail himself of this opportunity of research. His observatious at Ealing and Acton, following those of General Pitt Rivers, were the subject of several papers read before various scientific societies, aud ultimately formed the basis of his book, published in 1887, under the rather happy title of Palaolithic Man in N.W. Middlesex. This is the work by which Mr. Allen Brown is best known. 'The Journal of the Anthropological Institute, however, not to mention any other publication, testifies to his activity in various directions. In the prosecution of his studies he formed a collection, rich in the relics of prehistoric times in this country and in ethnological objects from many other parts of the world. Mr. Brown delighted to exhibit and explain this collection to those interested in the subject. In matters affecting the social development of his neighbourhood, such as the free library movement, he took a keen and active interest. Mr. Brown, in fine, was one of those useful local men who take an intelligent interest in their surroundings; and while he lived and was able to work, geologists and anthropologists might rest assured that no new section in the neighbourhood was likely to escape his vigilance. It is worthy of note that Mr. Johu Brown, the father of Mr. J. Allen Brown, was largely instrumental, sixty years ago, in founding the Ethuological Society, which became merged in the Anthropological Institute.

F. W. RUDJ,ER.

\section{Africa, West. \\ Dalton. \\ Note on an unusually fine Bronze

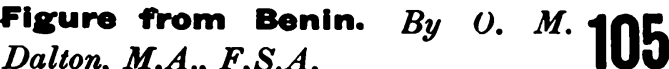

The ethnographical gallery at the British Museum has recently received a welcome addition in the shape of several bronzes from Benin presented;by Mr. E. J. K. Corner. They comprise four of the flat plaques or panels, two of the large cast heads such as were sometimes used to support carved ivory tusks, and the figure of a man reproduced by the uccompanying photograph. This figure is a remarkable example of its class, being no less than 2 feet 3 inches high, and is finely ornamented with punched designs. It is evident from the costume that the person represented is a retainer and not one of the noble or official caste. His costume resembles that seen upon numerous panels brought from Benin, and illustrates in an exceptionally clear manner the beluku or loin.cloth, with its end twisted up and stiffened at the left side of the wearer. The left arm is, unfortunately, wanting, and of the horn once grasped by the two hands there remains only the part to which the lips were applied. As the Museum is not very well off for figures cast in the round the present example forms au unusually desirable acquisition.

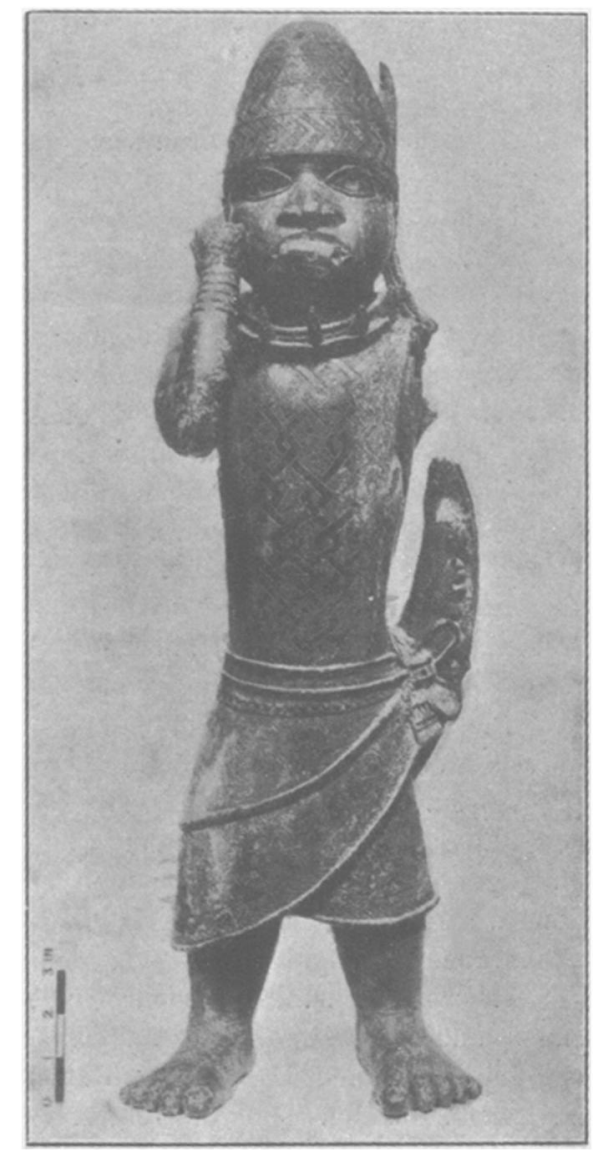

O. M. D.

FIGURE OF CAST BRONZE FROM BENIN. 